\title{
The connection between youth ministry's division of evangelism and discipleship, and the lack of retention of youth in North American churches
}

\begin{tabular}{|c|c|}
\hline \multicolumn{2}{|c|}{$\begin{array}{l}\text { Authors: } \\
\text { Kenneth A. Moser } 10 \\
\text { Malan } \mathrm{Nel}^{2} \text { (1) }\end{array}$} \\
\hline \multicolumn{2}{|c|}{$\begin{array}{l}\text { Affiliations: } \\
\text { 'Department of Youth } \\
\text { Ministry, Briercrest College } \\
\text { and Seminary, Caronport, } \\
\text { Saskatchewan, Canada }\end{array}$} \\
\hline \multicolumn{2}{|c|}{$\begin{array}{l}{ }^{2} \text { Department of Practical } \\
\text { Theology, Faculty of } \\
\text { Theology, University } \\
\text { of Pretoria, Pretoria, } \\
\text { South Africa }\end{array}$} \\
\hline \multicolumn{2}{|c|}{$\begin{array}{l}\text { Corresponding author: } \\
\text { Kenneth Moser, } \\
\text { kmoser@briercrest.ca }\end{array}$} \\
\hline \multicolumn{2}{|c|}{$\begin{array}{l}\text { Dates: } \\
\text { Received: } 28 \text { May } 2019 \\
\text { Accepted: } 16 \text { July } 2019 \\
\text { Published: } 20 \text { Nov. } 2019\end{array}$} \\
\hline \multicolumn{2}{|c|}{$\begin{array}{l}\text { How to cite this article: } \\
\text { Moser, K.A. \& Nel, M., 2019, } \\
\text { 'The connection between } \\
\text { youth ministry's division of } \\
\text { evangelism and discipleship, } \\
\text { and the lack of retention of } \\
\text { youth in North American } \\
\text { churches', Verbum et Ecclesia } \\
40(1), \text { a2020. https://doi. } \\
\text { org/10.4102/ve.v40i1.2020 }\end{array}$} \\
\hline \multicolumn{2}{|c|}{$\begin{array}{l}\text { Copyright: } \\
\text { ( ) 2019. The Authors. } \\
\text { Licensee: AOSIS. This v } \\
\text { is licensed under the } \\
\text { Creative Commons } \\
\text { Attribution License. }\end{array}$} \\
\hline \multicolumn{2}{|l|}{ Read online: } \\
\hline 回触 & $\begin{array}{l}\text { Scan this QR } \\
\text { code with your } \\
\text { smart phone or } \\
\text { mobile device } \\
\text { to read online. }\end{array}$ \\
\hline
\end{tabular}

The evangelical church in North America is facing a crisis in its failure to retain young people. Research has shown that young people are dropping out of the church and they are not only leaving but also failing to return once they are older. This crisis did not appear in a vacuum; it is the result of the church's movement towards a style of programming that has created a division between evangelism and discipleship. This style of programme not only seeks to reach those outside of the church at the expense of those youth in the church but also creates a dichotomy between who we are (our identity) and what we do (our mission). The church must seek to remove this dichotomy between identity and mission and utilise strategies that work with our identity rather than against it.

Intradisciplinary and/or Interdisciplinary Implications: This article is an interaction between practical theology and pastoral practice in Christian ministry. The crisis of youth leaving evangelical churches in North America is because of the dichotomy between mission and identity. Once this dichotomy is erased, mission will be a natural outworking of identity in youth ministry.

Keywords: youth ministry; retention; identity; mission; evangelism; discipleship.

\section{Introduction}

I write this article as a youth ministry practitioner and a teacher of youth ministry in Canada. The church in Canada, as well the United States to our south, is in a crisis because of a failure to retain young people. A quarter of a century ago, American historian Mark Senter called for a 'revolution' in youth ministry and urged a 'total restructuring' in our methodology. Citing the coming changes that would impact young people, he wrote, 'continued modifications of the current system simply will not keep up with the changes in the world in which we live' (Senter 1992:29). Twenty years later, Mike Yaconelli, co-founder of the influential Youth Specialties, a major youth ministry resource for training and publishing youth ministry resources in the United States, stated, 'youth ministry as an experiment has failed', and, 'the success of youth ministry in this country is an illusion ... very little youth ministry has a lasting impact on students'. His contention was that we need to 'completely change the way we do youth ministry in America' (Yaconelli 2003).

While Senter and Yaconelli's sentiments may not have been widely popular in 2003, they are now being reiterated from a number of youth ministry writers. Mark Oestreicher, the former head of Youth Specialties, echoes Yaconelli's words, stating that youth ministers in North America are 'failing at our calling' and we need 'an epochal shift in our assumptions, approaches, models and methods' (Oestreicher 2008:20). Others are joining Oestreicher in calling for a rethink in North American youth ministry strategy. Andrew Zirschky (2012) claims that youth ministry is 'broken' and asserts that:

Despite all the guidance we've received from educators and psychologists, it's clear that it's not working. Teenagers come to church in droves to play games and hear a Bible lesson, but then they walk away from the faith. (n. p.)

Mike King urges the need to critique our practices 'out of love for the church and a desire for it to be truly evangelical' (King 2006:26). Chris Folmsbee has called for a 'reculturing of youth ministry' (Folmsbee 2006:16). Finally, Andy Root has sounded an alarm, citing anthropologists who observe that a 'community's health can be assessed by the well-being of its children' (Root 2011:16). Root says, 'Given the continued hemorrhaging of young people from American churches, Christian communities have cause for concern' (Root 2011:16). There seems to be a general consensus that 
youth ministry in North America is in crisis because of the inability to produce long-term members. Kinnaman has called the present time a 'critical point in the life of the North American church' (Kinnaman 2011:13). He has critiqued the modern church saying, in our rapidly changing culture the paradigms and assumptions that guide our thinking in youth ministry are 'rooted in modern, mechanistic, and mass production paradigms' (Kinnaman 2011:13). What does it mean for modern youth ministry to drop these 'mass production paradigms' and adopt a new strategy?

The research problem that I wish to address in this article is the connection between our retention (the loss of youth from our church) and our commitment to attracting newcomers at the expense of spiritual practices. In other words, is there a connection between the programme we use to attract youth from outside of the church and the loss of youth from inside of the church? It is my belief that because of a number of factors we have adopted a methodology that actually works against producing young people in the church who will stay long term. While this article deals with the church in North America, the issues addressed are relevant to the wider church across the globe.

\section{The crisis facing North American youth ministry}

The numbers of young people in the church have been consistently declining, and there does not appear to be a reversal of this in the near future. The Barna Group has documented diminishing attendance among youth in the churches of the United States. Their findings show that only one-fifth of the people in their 20s have maintained a level of spiritual activity consistent with their high school experiences (Barna Group 2006). Kinnaman claims that of those people who had a Christian background as a youth, $59 \%$ report that they had or have 'dropped out of attending church, after going regularly'. His research has found that $57 \%$ of people who were active in Christian fellowship during their youth say they are less active in church today compared to when they were aged 15 years (Kinnaman 2011:23). According to LifeWay Research and Ministry Development, an organisation that represents the sizable Southern Baptist Convention in the United States, as teens grow older, their frequency of attendance drops (LifeWay 2007). Krejcir (2007) notes that the:

$[P]$ roportion of the population that is Protestant has declined markedly in recent decades while the proportion of the population that is not affiliated with any particular religion has increased significantly. (n. p.)

Clark notes that the regular Canadian church attendance rate for people aged 15-24 years was 34\% in 1988. By 1998, when they were $25-34$ years old, the rate had dropped $10 \%$ points to $24 \%$ (Clark 2000:23). Statistics from the Pew Research Centre show that for young people raised in the church, $44 \%$ now claim to be 'currently unaffiliated with any particular religion’ (Pew 2008:29).
The recent Hemorrhaging Faith study of almost 3000 young people by the Evangelical Fellowship of Canada has pointed out the ineffectiveness of the Canadian Church to hold onto its youth. The survey reports that only one in five youth who attended a Catholic or Mainline Protestant church from 1980 to 1999 still attend church. According to their research, evangelical churches have more success but still have $50 \%$ of their youth dropping out of church affiliation. Furthermore, the authors state that young people are dropping out of church before they leave high school. Their results found that 'the decline in attendance between childhood and the teen years is greater than the subsequent decline between the teen years and young adulthood' (Penner et al. 2011:21). This study also showed that not only are youth dropping out of the church in North America but they are also tending not to return to it once they are older. In Canada, those who leave the church of their youth do not move onto another Christian church. In fact, 'the majority are identifying as atheist, agnostic, spiritual or none' (Penner et al. 2011:25). In the United States, this trend is similar. The Barna Group's research claims that only one-third of parents in their 20s regularly go to church with their children. This is compared to two-fifths of parents in their 30s and one-half of those parents who are 40 or older (Barna Group 2006). This indicates that adults who were involved in youth group when they were younger are not returning to church.

It has been my experience in three decades of youth ministry that the observations above are indeed true; we are failing at producing longevity when it comes to the Christian faith. The recent Hemorrhaging Faith report has provided clear data showing this to be true of youth ministry in Canada. The theme of this article comes out of this experience and seeks to ask a very specific question: Is there a connection between the failure to produce longevity in the lives of Christian young people and the means we have used to attract these youth (those both inside and outside the church) to our youth programmes? It is also my belief that, while much of the research that I have cited comes from North America, the findings are relevant to other parts of the world as well.

\section{A brief history of modern youth ministry in North America}

North American youth ministry has long been characterised by a focus on entertainment and the pursuit of fun to attract non-Christian young people. It is the norm that youth group must have fun as this will attract unchurched youth to the church. In addition to attracting the unbeliever, fun is seen as an essential component to engage with, and ministry to, those youth already in attendance. Jacober (2011) has noted:

We have been taught both formally and through expectations of the church (or parachurch or other Christian organizations) that it is better to throw a good party with a lot of adolescents than to intentionally enter into ministry with one. (p. 9)

Creasy Dean describes much of youth ministry as a 'diner theology: a bargain religion, cheap but satisfying, whose 
gods require little in the way of fidelity or sacrifice (Dean 2010:10)'. Urbanski (2000) reflects these sentiments saying:

To just about everybody- save for those of you reading these words- the youth ministry job description must look like a piece of cake: Hang out with the kids, order pizza, play some games, sing some songs, etc. etc. (p. 1)

Jeff Anderle (1995), in an article written almost 20 years ago, sums up the crisis he and others were facing:

For five years I followed the typical youth group structuresinging, crowd breakers, entertaining activities. We even spent a little time talking about Christ. But sometime between wiping egg off the floor from our latest gag and dreaming of the Video Toaster that would catapult me into big time youth ministry, the question hit me: What am I doing? I realized our youth program wasn't imparting to kids the essentials for their spiritual growth. Even I related with Christ as though he were a vaguely remembered distant relative rather than an energizing friend. Our program based ministry, since it did little to change kids, had burned me out. (p. 14)

Note especially Anderle's understanding of a typical youth group structure: '... singing, crowd breakers, entertaining activities. We even spent a little time talking about Christ'. Fun activities appear to have been generally accepted as the standard approach to youth ministry programming. It is time that we must ask the questions: Where did this understanding of youth ministry come from? And, is this a helpful picture of youth ministry in today's world? To answer these questions, an examination of our past is a necessary and helpful key to understanding our present crisis.

North American youth ministry in the 1930s and 1940s underwent a seismic shift as two major organisations were formed with the desire to reach those outside of the church. This desire led to the utilisation of entertainment rather than Christian practices. These organisations - Youth for Christ and Young Life - have profoundly shaped much of our understanding, structure and operation of youth ministry. They have also helped to shape the strategy of dividing of evangelism and discipleship that has had a major impact on modern youth ministry. To understand the formation of these organisations, it will be helpful to first understand the impact of radio.

Hart has stated that, as far back as the First Great Awakening in America, evangelical Christians have shown 'an ability for exploiting new communications technology and business practices to advance religion' (Hart 2002:174-175). Ward adds that 'twentieth-century American religious cultural phenomena, from evangelical celebrities to evangelical music, are hardly comprehensible without religious radio' (Ward 2013:102). In the early 20th century, the emergence of radio as a common form of communication and entertainment is one key factor in the quest to understand the development of modern youth ministry. One of the main reasons for this is simply the availability and rapid increase in ownership of radios in American households. In the 1930s, two-thirds of
American households owned a radio, and by 1940, the figure had risen to over 80\% (Sterling \& Kittross 1978:533). Radio had an impact not only on North American culture generally but also on Christian evangelism. Christians who were involved in evangelism were quick to discover radio as a means to amplify their message to a wider audience. More importantly people were not only listening to the radio but also listening to programmes of high quality. This resulted in some Christian evangelists believing that secular radio had set a high standard of entertainment that must be met if one was to reach the youth of the day. Carpenter notes that Billy Graham was influenced by radio announcers mimicking 'their timing and timeliness with his own passion to save lost souls' (Carpenter 1990:217).

Torrey Johnson, the first leader of Youth for Christ and a key figure in the development of youth ministry in the 20th century, wrote: 'Isn't radio part of every youngster's environment today? Furthermore, doesn't the world present its best via radio?' (Johnson \& Cook 1944:37). In his mind, this meant that any attempts to evangelise youth had to be of the same quality as the entertainment the world provided. Johnson would urge evangelists to understand this high standard and to figure out what type of events youth would attend. Speaking of evangelistic gatherings, he wrote: 'Dare to offer them something shoddy, and they'll shun your meeting' (Johnson \& Cook 1944:36).

In the late 1930s and early 1940s, Youth for Christ and Young Life, two prominent parachurch youth ministries, were formed that utilised entertainment as a prominent feature in their evangelistic endeavours. These two movements are pivotal to understanding the development of modern youth ministry. The direct influence of these two parachurch youth ministries is paramount for an examination of modern youth ministry trends and programming strategies. Borgman calls Young Life's influence on contemporary youth ministry both 'broad and unmistakable' (Borgman 1987:69). Senter agrees, stating that 'churches have flattered the movement by imitating its strategies and methods' (Senter 1992:22). Jay Kesler, the former president of Youth for Christ USA., comments: 'There are very few things done in youth work that were not pioneered in Youth for Christ or Young Life - be it in Christian camping, various small group activities or music' (Schultz 1985:22).

While the constraints of this article forbid a full treatment of these two organisations, there are a few key areas that must be examined. The first is the motto of Youth for Christ: 'geared to the times and anchored to the rock'. This simple motto reflected the methodology of this organisation: preach the message of Christ ('the rock'); however, use culturally relevant and appropriate ways to do so. The backbone of Youth for Christ was the Saturday evening rally. Designed for those outside of the church, it was organised with a programme that, in Shelley's (1986) words, consisted of:

$[L]$ ively gospel music, personal testimonies from athletes, civic leaders or military heroes and a brief sermon, climaxing with a 
gospel invitation to receive Jesus Christ as personal Savior. This was revivalism tailored to youth. (p. 49)

The programmes often included entertaining acts such as magic, a talented whistler and musical oddities such as saws and single-string oil cans (Shelley 1986:49). In addition to an entertaining programme, the leaders on stage themselves were entertaining, wearing, according to Hefley, 'brashy' wide ties and even ties with battery-powered lights that would blink along with choruses such as 'This Little Light of Mine' (Hefley 1970:14). What could be considered an extreme example was 'MacArthur the Gospel Horse', who knelt before a cross during singing, moved his jaws and would answer Bible questions via tapping a hoof (Hefley 1970:17).

While Youth for Christ was forming, another organisation, Young Life, was founded by Jim Rayburn. Rayburn's influence cannot be overstated with Senter, describing Rayburn's youth ministry strategy as fundamentally different from anything that had preceded it (Senter 2010:218). There are a number of areas where Rayburn's ministry is still felt in youth ministry today, primarily, his desire to reach young people outside of the church. He would do this by befriending unchurched youth with the hope of presenting the Christian faith in a way that was enjoyable and full of zeal (Meredith 1978:20-21). His goal was to remove the impression that church was, in his words, 'boring' (Rayburn 1984:62). Rayburn is widely known for the phrase, 'It's a sin to bore a kid with the gospel' as it was Rayburn's view that kids should have 'one heck of a good time' while hearing about Jesus (Meredith 1978:72). Meredith, in her study of Young Life, says that in this movement's youth gathering, 'entertainment was a key thing in proclaiming the gospel, it was a spiritual matter' (Meredith 1978:72). This concept of fun and entertainment in relation to evangelism became a key idea in Young Life's ministry strategy (Meredith 1978:72).

The influence of these two organisations has widely impacted evangelism. Both of these organisations have, at their heart, what Ladd and Mathisen refer to as a revivalist mindset, that is, the desire for conversion and the evangelisation of unchurched youth (Ladd \& Mathisen 1999:233). This has caused a shift in the minds of many youth leaders to see youth group as a place for the unchurched youth rather than a gathering of like-minded Christian young people. In addition, Bergler notes that these two groups 'set the pattern' for modern youth ministry with a programme of songs, games, skits and entertainment followed by more serious segments such as a talk or Bible study that are packaged with humour, stories and personal testimonies. He notes that this pattern appeals to the desire that youth have for fun and belonging (Bergler 2012:220). Bergler comments that the leaders of Youth for Christ promised teenagers that they could 'have fun, be popular, and save the world at the same time' (Bergler 2012:148). In fact, Bergler (2012:151) uses the term 'fun consecration' when describing the organisation.

\section{Youth specialties}

The methodology set into place by Youth for Christ and Young Life would be taken a step further by two key youth leaders in the 1960s: Wayne Rice and Mike Yaconelli. Rice and Yaconelli, who initially worked for Youth for Christ, began their widespread influence by selling books filled with ideas for a weekly youth group gathering. The popularity of these books would lead to the formation of Youth Specialties, a company devoted to the resourcing, training and spiritual care of youth leaders and one that would be, to the present day, a major influence in youth ministry in North America. Senter states that their 'visibility, creativity, and insights in the world of youth ministry soon made them a part of a newly established power block' (Senter 2010:251). Rice comments that although their business started 'on a whim', it grew to 'become one of the largest providers of youth ministry training and resources in the world' (Rice 2010:16).

In Rice's Youth for Christ experience, anything that was entertaining could be used to attract young people. Leaders used a variety of entertaining skills and music, including stand-up comedy, magic and ventriloquism. All of these were to 'have more tricks of the trade at their disposal for keeping kids' attention' (Rice 2010:63). Rice's experience, along with Yaconelli, was built on the understanding that youth ministry was all about 'finding ways to reach unchurched teens with the good news about Jesus' (Rice 2010:64). This necessitated, in their minds, the need for attractive, entertaining programme ideas.

Rice and Yaconelli's impact on modern youth ministry in North America cannot be overstated. Cusick claims that the impact of Youth Specialties is immense servicing over 70000 organisations, including the YMCA, Boy Scouts of America, the United States Air Force, the Salvation Army and thousands of churches (Cusick 1995:67). One writer has called their influence 'staggering, impacting hundreds of thousands of youth leaders all across the globe' (Webster 2003), with another claiming that 'Youth Specialties not only changed youth ministry but created modern youth ministry as we know it' (Jones 2009).

It is evident from the study of Youth for Christ, Young Life and Youth Specialties that their strategy was to focus on the evangelisation of those outside of the church. This methodology was built on the desire to attract young people through anything deemed to be culturally relevant and alluring. This methodology has been called 'attractional ministry'. Frost and Hirsch define attractional ministry as 'an approach to Christian mission which the church develops programmes, meetings, services, or other products in order to attract unbelievers in the influence of the Christian community' (Frost \& Hirsch 2013:273). It is their view that the church relies on this model as the main approach to attracting new members to join its ranks. In youth ministry, this is seen in the fact that what is used to reach the unchurched must be relevant to them, attractive, and bring 
them to a setting where they can hear a Christian message that gives them the opportunity to respond. It is also reflected in the commonplace use of games as a major part of our programme content.

It has been my observation that, while the methodology of our past has deeply shaped our commitment to reaching outsiders through 'fun', most youth leaders simply do not run an evangelistic gathering alone. Many youth leaders see the need to have some other programme committed to building strong disciples. This can either be on another night of the week (i.e. Friday night is evangelism, Wednesday night is discipleship) or, more commonly, it is simply seen in a weekly gathering that has been referred to as 'the cocktail', with one part 'fun' (to reach out) and one part 'serious' (to build up) (Moser 2004). The former programme (one night evangelistic, one night discipleship) is part of a youth ministry strategy advocated by systems such as Duffy Robbins' Funnel or Doug Fields' baseball diamond. In these systems, youth are moved from one programme to another with increasing spiritual content and an increased depth of spiritual maturity. The latter programme ('the cocktail') is run mainly because of a lack of means. To run multiple programmes requires more resources than many churches can afford.

There ought to be a concern in the use of worldly attraction. This, in turn, leads to the division of evangelism and discipleship which is a division of our identity and our mission. That is, who we are and what we do.

\section{Our identity and our mission}

At the heart of our understanding of youth ministry must be a theological reflection built around two questions, one of identity (Who are we?) and the other of mission (What is our task?). Because of the influences of the last century, youth ministry has now separated these two when it comes to programming. On the one hand, the typical youth programme regards itself as a Christian group typified by following Jesus and those qualities that would normally be seen to be 'Christian' (e.g. faith, love and hope). In addition, it hopes to produce spiritual maturity through disciplines such as prayer and Bible study, as spiritual maturity is the desired identity. However, what has often consumed these groups is a desire to grow numerically, which thus becomes their mission. In attractional programming, we see mission divorced from identity, that is, we employ methods of reaching the lost that do not reflect our identity as the body of Christ on earth. For example, reflect on a youth ministry promotional video or clip that you may have recently seen. Is it built on Christian practices and activities that typify a Christian gathering (Bible reading, prayer or songs of praise)? Or, does it show a group of youth running around engaged in some energetic activity? The goal of this article is not to espouse a dour youth ministry, but rather to point out that the identity of youth ministry has shifted from spiritual characteristics and pursuits to those deemed culturally attractive at any given time.
In addition to this, many groups have struggled with the balance of 'preservation' and 'propagation' (Nel 2015:116). That is, they fail to move beyond their mission (the desire to reach the unchurched) to a development of their identity, that is, a Christian youth group characterised by the mores and practices of the Kingdom of God. In other words, the mission of reaching the lost has 'won out' over identity (spiritual maturity). It is my belief that this failure to understand the relationship between our identity and mission has been a key factor in the decline in youth ministry.

The church must be a place that is, by its very nature, missional (Nel 2018:23). Grenz states that our identity is 'led by the Spirit' and 'participates together in the fellowship of the Triune God'. This missional identity, Grenz says, is the foundation for our ministry in the world (Grenz 1998:217). The ministry of evangelism and discipleship, like all the various ministries of the church, must form a "whole and beautiful unity' that furthers the 'communication of the gospel in service of God, one another, and the world' (Nel 2015:78). In doing so, they must be connected, without prioritising one over another. Armstrong agrees, calling us to see that evangelism is at the heart of our mission - it is not something we do, but rather who we are (Armstrong 1979:66). Bosch's insights here are helpful as he encourages the Christian community to see that it is in mission where we find our true identity, as we bring the message of new life and salvation to this world (Bosch 1991:83).

There must no longer be a perceived split between who we are and what we do. It is ineffective to divorce our desire to reach out and our core identity as disciples of Jesus who pursue spiritual maturity. Whether it is a programme that runs on two nights or a cocktail, there must be a merging of evangelism and discipleship. In addition, our identity (disciples of Jesus Christ) is also our great strength in reaching those outside of the church. Think of it this way; if a cricket team desires to grow, what should it do well? The answer ought to be, play cricket! We find ourselves, however, in a situation where we are not only failing to keep our youth in the church but also failing to promote effectively who we are.

Wilhoit urges us to see that an effective ministry philosophy must be shaped through a careful study of Scripture and continually re-evaluated in light of a constant study of the Word of God (Wilhoit 1991:69). Root echoes this, noting that the normative texts of the Christian tradition are essential in our theological thinking (Root \& Creasy Dean 2011:43-44). Stated simply, one of the key factors that precipitated the crisis in youth ministry in North America was the failure to build lasting Christian maturity into the lives of young people. Dean and Foster offer a stinging rebuke of modern youth ministry practices, claiming they have been inadequate in helping young Christians to become spiritually mature. They claim that instead of meeting the spiritual needs of young people and providing avenues that promote maturity, we have provided entertainment in its place. They believe 
that while youth are looking for something or someone that is 'capable of turning their lives inside out and their world upside down', we have 'offered them pizza instead' (Dean \& Foster 1998:9).

This is an area where we must think carefully about the interplay between our culture and our theology. Youth ministry has failed to live out its theology in modern culture. If one holds to a position of 'evangelism as the priority' as the Attractional Model of youth ministry advocates, it must not be to the neglect of building the faith of young people who are already in the church, as well as those newcomers we successfully reach.

\section{Towards a new way of thinking about youth ministry}

Richard Osmer urges us to see a partnership between 'divine disclosure' (God's word) and our own 'shaping of this word'. A 'prophetic discernment', according to Osmer, is needed to critique our inherited theologies and also to interpret the vagaries of the culture we are operating in (Osmer 2008:134-135). This concept of examining our inherited theologies as we apply them to our ethics and practice will allow us to continue to apply scripture to our cultural contexts without losing our way to our theological or ideological biases. With this, Osmer encourages a constant questioning of our own theological interpretations and how they are operating - successfully or unsuccessfully in our culture. It is my belief that given the new cultural forces at work, forces such as the availability of sophisticated and easily accessible entertainment must cause us to revisit our assumptions, and assumptions such as 'entertainment will be effective in reaching young people with the gospel of Jesus Christ'.

Root has exhorted us to reflect on 'the layered meaning of a performance in a context' (Root 2007:58). Like all crises, this one is many-layered. However, as we peel back these layers, we must be prepared to thoughtfully adopt strategies that can reverse our crisis. Many practitioners of youth ministry in Canada and the United States have a number of deeply held theological assumptions that have directed the way we perform youth ministry. As I have pointed out earlier in this article, these assumptions have not come about by chance they are a direct result of our history. However, they must be reflected on critically, especially in light of the crisis facing the church in North America.

As the modern church 'peels back the layers' of our work with youth, we must reflect and rethink our attachment to our past and the movements that have continued to shape modern practice. Much earlier in this article, I noted Senter's challenge for a 'revolution' in the way we understand youth ministry, and it is an imperative that we must heed; it is my belief that we must restructure the way we think about youth ministry. As we head towards a conclusion of this article, a question must be asked, Does attractional youth ministry, combined the division of evangelism and discipleship, work against producing those elements of youth ministry that will result in positive long-term results?

One key area that this article has sought to raise is how youth ministry engages missionally with those outside of the church. It is clear from our history that youth ministry has, since the late 1930s, been interested in reaching those who do not attend church. However, our missional focus must come from and be deeply connected to our identity as God's people. We are indeed 'God's search parties' (Nel 2015:38) and this springs from living out our identity as God's kingdom. This ought to be seen in activities that spring from this identity, spiritual practices such as prayer, Bible study and evangelism rather than those activities deemed culturally attractive. It is my belief that we are simply not skilled enough to compete with the world. In addition, I wonder if our commitment to attractional youth ministry has undermined our effectiveness rather than enhanced it. Would it be better to run a programme that, while designed to reach the non-Christian, is built on activities, spiritual disciplines and community development that 'cuts with the grain' of our identity rather than against it?

With the above comments in mind, there are a number of areas the church will need to address. The first one is obviously that of youth ministry identity. The church must ask, 'What ought to be the identity of our youth group?' It is my belief that youth ministry in North American has an identity that has bound itself to a 'vicious cycle' that produces a lack of retention. What I mean is that what is used to attract young people, namely entertainment and games, has produced a group with the identity of people who come for entertainment and games. This leads to a deficiency in the spiritual development of its members and a paucity of those factors that promote longevity in the Christian life - factors such as prayer and Bible reading. This will then lead back to a lack of retention in the programme.

Another issue that the church should reflect on is the youth (and youth group's) relationship with the larger church body. How does the church connect its young people into the life of the congregation? This is an important question. How does the church be 'youth-friendly' without compromising core values or adopting gimmickry? I am reminded of one church elder who bemoaned the fact that the church regarded its young people as 'accessories' rather than integral members of the church, not to mention the very future of the church. One issue for the church to consider is the need to move away from any programme that constructs a youth ministry as a separate entity that has little to no involvement with the life of the other congregants. Rather, it should be seen as the youth arm of the church.

For this to happen, the youth group must focus on those features that the church is committed to, features such as effective Christian living, spiritual maturity and spiritual disciplines. If these are manifested in a way that is 
'youth-friendly', they may also be evangelistically effective. A focus on Christian practices will also make the transition from youth group to church an easier one as they will be characterised by the same practices.

My reading of history leads me to wonder if, in our dedication to the pursuit of those outside of the church, we have neglected the spiritual development of the young person who is already in the church. There has been, in essence, a 'reaching around' of this young person to attract a young person outside of the church, often at the expense of those whom we already have. In the end, we are now in a position where many groups do not attract and do not keep.

I have stated earlier that Osmer has challenged us to question how our own theological interpretations are operating in our culture. Are they successful or unsuccessful? With this in mind, I am left to wonder about the inherent drop-in nature that accompanies many attractional youth ministries - it certainly follows a programme that divides evangelism from discipleship. If the target audience decides that what is offered is not attractive, they simply do not need to come. Therefore, does a youth ministry that is attractional inhibit the development of community because of this 'drop-in nature?' Furthermore, in lieu of a very 'busy' modern society, is there now a new entry-level needed, that is, the need for a commitment mindset? Does the person outside of the church need to be convinced of the benefits of 'putting aside other things' (such as sports) to explore the youth ministry programme instead? If so, the splitting of evangelism and discipleship will prove to be unhelpful. The church must focus instead on a commitment mindset that will aid in the development of community.

\section{Conclusion}

I do not wish to provide a band-aid solution to a complex problem. However, for the church to reverse the crisis in retention, the solution may simply lie in being the church. Our strength is in being who we are - disciples of Jesus Christ. In the Scriptures, we see an intimate connection between our identity (and the core practices that go with this identity) and numerical growth. John 13:35 tells us that if we are loving (identity), all will know we are disciples of Jesus (mission). In Matthew 5:13-16, we are told that if we are holy (identity), people will see this holiness and praise our heavenly Father (mission). Peter 3:15 tells us that if we are characterised by Jesus living in our hearts (identity), we must be prepared to speak about our hope (mission).

\section{Acknowledgements Competing interests}

The authors have declared that no competing interest exist.

\section{Authors' contributions}

K.A.M. wrote the article and M.N. did the supervision.

\section{Ethical considerations}

This article aims to present a fair assessment of the issue of young people leaving the church using public access youth ministry resources. No resources used required confidentiality. All reference sources cited.

\section{Funding information}

This research received no specific grant from any funding agency in the public, commercial, or not-for-profit sectors.

\section{Data availability statement}

Data sharing is not applicable to this article as no new data were created or analysed in this study.

\section{Disclaimer}

The views expressed in this article are those of K.A.M. and not an official position of any institution or funder.

\section{References}

Anderle, J., 1995, 'High school minister', Youthworker Winter 1995 issue, p. 14. Armstrong, R.S., 1979, Service evangelism, The Westminster Press, Philadelphia, PA.

Barna Group, September, 2006, Most twenty somethings put Christianity on the Shelf following spiritually active teen years, viewed 07 November 2012, from https://www.barna.org/barna-update/article/16-teensnext-gen/147-mosttwentysomethings-put-christianity-on-the-shelf-following-spiritually-active-teenyears\#.Uecg9hZhgeM.

Bergler, T.E., 2012, The juvenilization of American Christianity, William B. Eerdmans Publishing Company, Grand Rapids, MI.

Borgman, D.A., 1987, 'History of youth ministry', in W. Benson \& M. Senter (eds.), The complete book of youth ministry, Moody Press, Chicago, IL.

Bosch, D.J., 1991, Transforming mission: Paradigm shifts in theology of mission, Orbis Books, Maryknoll, NY.

Carpenter, J., 1990, Youth for Christ and the new evangelicals' place in the life of the nation', in R.A. Sherrill (ed.), Religion and the life of the nation, pp. 128-151, University of Illinois Press, Urbana, IL.

Clark, W., 2000, 'Patterns of religious attendance', Canadian Social Trends, viewed 22 June 2018, from https://www.statcan.gc.ca/pub/11-008-x/2000003/article/5389eng.pdf.

Cusick, M., 1995, 'A conversation with Mike Yaconelli', Mars Hill Review 2(May 1995), pp. $67-87$.

Dean, K.C. \& Foster, R., 1998, The godbearing life: The art of soul tending for youth ministry, Upper Room Books, Nashville, TN.

Dean, K.C., 2010, Almost Christian: What the faith of our teenagers is telling the American Church, Oxford University Press, Oxford.

Folmsbee, C., 2006, A new kind of youth ministry, Zondervan, Grand Rapids, MI.

Frost, M. \& Hirsch, A., 2013, The shaping of things to come: Innovation and mission for the 21st century, Baker, Grand Rapids, MI.

Grenz, S.J., 1998, Created for community: Connecting Christian belief with Christian living, Baker Academic, Grand Rapids, MI.

Hart, D.G., 2002, That old-time religion in modern America, Ivan R Dee, Chicago, IL.

Hefley, J., 1970, God goes to high school, Word, Waco, TX.

Jacober, A.E., 2011, The adolescent journey: An interdisciplinary approach to practical youth ministry, InterVarsity Press, Downers Grove, IL.

Johnson, T. \& Cook, R., 1944, Reaching youth for Christ, The Moody Bible Institute, Chicago, IL.

Jones, C., 2009, Influences: Mike Yaconelli, viewed 05 September 2014, from https:// youthguy07.blogspot.ca/2009/12/influences-mike-yaconelli.html.

King, M., 2006, Presence-centered youth ministry, InterVarsity Press, Downers Grove, IL.

Kinnaman, D., 2011, You lost me, Baker Books, Grand Rapids, MI.

Krejcir, R.J., 2007, Statistics and reasons for church decline, Church Leadership.org, viewed 22 June 2018, from https://www.churchleadership.org/apps/articles/ default.asp?articleid $=42346$.

Ladd, T. \& Mathisen, J.A., 1999, Muscular Christianity: Evangelical protestants and the development of American sport, Baker Books, Grand Rapids, MI. 
LifeWay Research, 2007, Reasons 18- to 22-year-olds drop out of church, viewed 19 May 2015, from https://www.lifewayresearch.com/2007/08/07/reasons-18-to22-year-olds-drop-out-of-church/.

Meredith, C., 1978, It's a sin to bore a kid, Word Press, Waco, TX.

Moser, K., 2004, Youth evangelism: Reaching young people in a way that honours god Changing the World Press, Vancouver.

$\mathrm{Nel}, \mathrm{M} ., 2015$, Identity-driven churches: Who are we and where are we going?, Biblecor, Wellington.

Nel, M., 2018, Youth ministry: An inclusive missional approach, HTS Religion \& Society Series, vol. 1, AOSIS, Cape Town. https://doi.org/10.4102/aosis.2018.BK83.00

Oestreicher, M., 2008, Youth ministry 3.0, Zondervan, Grand Rapids, MI.

Osmer, R., 2008, Practical theology, an introduction, William B. Eerdmans Publishing Company, Grand Rapids, Ml.

Penner, J., Anderson, E., Desorcy, B., Harder, R. \& Hiemstra, R. Hemorrhaging faith Why \& when Canadian young adults are leaving, staying \& returning to the church, A Foundational Research Document Commissioned by the Evangelical Fellowship of Canada (EFC) Youth and Young Adult Ministry Roundtable.

Pew Forum, February 2008, U.S. religious landscape survey: Religious affiliation: Diverse and dynamic, viewed 22 June 2018, from https://www.pewforum.org/ files/2013/05/report-religious-landscape-study-full.pdf.

Rayburn, Jim III, 1984, Dance children dance, Tyndale House Publishers Inc., Wheaton, IL.

Rice, W., 2010, Reinventing youth ministry (again), InterVarsity Press, Downers Grove, MI.

Root, A., 2007, Revisiting relational youth ministry, InterVarsity Press, Downers Grove, Ml.
Root, A., 2011, 'God is a Theologian', in K.C. Dean \& A. Root (eds.), The theological turn in youth ministry, InterVarsity Press, Downers Grove, MI.

Schultz, T., 1985, 'What's happened to young life and campus life?, Group, May 1985 issue, pp. $16-23$.

Senter, M., 1992, The coming revolution in youth ministry, Victor Books, Wheaton, IL.

Senter, M., 2010, When god shows up: A history of protestant youth ministry in America, Baker, Grand Rapids, MI.

Shelley, B., 1986, 'The rise of evangelical youth movements', Fides et Historia 18(1), 47-65.

Sterling, C.H. \& Kittross, J.M., 1978, Stay tuned: A concise history of American broadcasting, Wadsworth Publishing Company Inc., Belmont, NC.

Urbanski, D., 2000, 'Staring down the spectre', Youthworker May/June 2000, p. 1.

Ward, M., 2013, 'Air of the king: Evangelicals and radio', in R.H. Woods (ed.), Evangelical Christians and popular culture, pp. 101-118, Praeger, Santa Barbara.

Webster, D., 2003, Grace gives life, abundantly: Mike Yaconelli, Siskiyou County's most influential resident, dies in a car crash on I-5, p. 1, Pioneer Press, p. 1, Fort Jones, CA, viewed 03 November 2018, from http://www.mikeyaconelli.org/articles/ pioneer.php.

Wilhoit, J., 1991, 'Developing a philosophy', in R. Clark, L. Johnson \& A. Sloat (eds.), A Christian education: Foundations for the future, Moody Press, Chicago, IL, p. 69.

Yaconelli, M., 2003, 'The failure of youth ministry', Youthworker May/June 2000, p. 64.

Zirschky, A., 2012, Practical theology as the foundation of youth ministry, viewed 06 February 2013, from https://www.cymt.org/practical-theology-as-thefoundation-of-youth-ministry/. 